\title{
Whistleblowing in a Depraved Nigerian Economy: Challenges and Prospects
}

\author{
Ayamba, Itojong Anthony ${ }^{1}$ \\ ${ }^{1}$ Department of Public Administration, University of Calabar, Calabar, Nigeria \\ Correspondence: Ayamba, Itojong Anthony, Department of Public Administration, University of Calabar, Calabar- \\ Nigeria.
}

Received: October 26, 2018

Accepted: January 14, $2019 \quad$ Available online: January 18, 2019

doi:10.11114/ijsss.v7i2.3978

URL: https://doi.org/10.11114/ijsss.v7i2.3978

\begin{abstract}
Corruption in Nigeria, as in several other countries across the globe, is a serious scourge that continues to expose the country to developmental setbacks in the political, economic and social facets. Apart from the unquantifiable financial resources lost annually to corruption in the private and public sectors, almost all of Nigeria's security, social, ethnic, political and religious conflicts can be traced to corruption directly or indirectly. Whistleblowing, as an anti-corruption mechanism, has proven to be effective in many parts of the world. This paper, from a background of rentierism, attempts to examine the epistemology of Nigeria's whistleblowing policy as well as the effectiveness, limitations, and justifications for the enhancement of the policy. The descriptive design was employed as the methodology of the study. Data were obtained mainly from secondary sources. The Theory of Two Publics was employed as theoretical framework for the study. The paper identifies insufficient legal knowledge, fear of reprisals, lack of meaningful litigation, prebendalism/loyalty provisions, and cultural and historical barriers as some of the challenges of whistleblowing in Nigeria. The paper submits that the policy, though a viable one, but yet to get the backing of an enabling law as at the time of this study, should be delicately formulated, assertively promoted to the public, and speedily sent to the National Assembly for consideration and passage.
\end{abstract}

Keywords: corruption, anti-corruption, whistleblowing, rentierism, policy

\section{Introduction}

The problem of development in Nigeria today is not necessarily as a result of the scarcity of human and/or material resources. The lack or slow development in Nigeria can be attributed to the interminable pursuit among Nigerians to maintain or gain undue advantage(s) over fellow Nigerians. This is the foundation of ethnic politics, the basis for the separation between the elite and non-elite, between the poor and the rich, etc. which usually manifests in the insertion of additional but fraudulent transactions geared towards altering the standard trajectory of events and abusing positions of trust. The result of this can be summed up in one word: "corruption." The pursuit of Nigerians to gain or maintain advantages for themselves over other Nigerians and its resultant manifestation- corruption is the reason why successive governments in Nigeria have left a litany of public and private institutions, frameworks and initiatives to address the menace. Though some successes have been made over the years, the war against corruption in Nigeria has remained largely ineffective and made worse by the nonexistence of a coordinated strategy to the many initiatives to combat corruption in the country.

Corruption, according to Otite (1986), simply means "the pervasion of integrity or state of affairs through bribery, favours or moral depravity." When two or more persons have acted together to alter the structure of society or the behaviour of functionaries so as to bring about dishonest and debased situations, one may say that corruption has taken place. Section 46 of the Economic and Financial Crimes Commission Act 2004 also considers corruption to include the following:

non-violent criminal and illicit activity committed with the objective of earning wealth illegally either individually or in a group or organized manner thereby violating existing legislation governing the economic activities of governments and its administration and includes any form of fraud, narcotic drug trafficking, money laundering, embezzlement, bribery, looting and any form of corrupt practices, illegal arms deals, smuggling, human trafficking and child labour, illegal oil bunkering, illegal mining, tax evasion, foreign 
exchange malpractices including counterfeiting of currency, theft of intellectual property and piracy, open market abuse, dumping of toxic wastes and prohibited goods, etc.

In spite of the huge spending made by successive governments in the fight against corruption, Nigeria continues to falter in terms of the standards and requirements of an effective anti-corruption regime as embodied in regional and global anti-corruption conventions, in particular the United Nations Convention Against Corruption (UNCAC) 2003, which Nigeria ratified on the 14th of December 2004. For instance, the current administration of President Muhammadu Buhari has made the fight against corruption and the restoration of integrity in governance a top priority. This is manifest in the President's commitment at the May 2016 London Anti-Corruption Conference; the setting up of the Presidential Advisory Committee on Corruption (PACC); establishment of the National Prosecution Coordination Committee (NPCC); the adoption of National Anti-Corruption Strategy (NACS) (2017-2020); the re-submission of two key anti-corruption bills: the Mutual Legal Assistance in Criminal Matters Bill and the Money Laundering (Prohibition and Prevention) Bill to the National Assembly for expedited consideration; the ongoing review of both the Nigeria Financial Intelligence Agency Establishment Bill, and the Proceeds of Crime Bill; the commitment to prosecute corrupt public officials; the recovery of looted public funds; the development of various justice sector reform initiatives; the Federal Ministry of Finance Whistleblowing Programme; and the recent Presidential Order No. 6 of 2018 on the preservation of suspicious assets connected with corruption and other relevant offences.

However, corruption is getting worse in Nigeria, according to the latest Corruption Perception Index (CPI) released by Transparency International (TI) on February $21^{\text {st }}, 2018$. While the country scored $27 / 100$ and was ranked 136th in 2016, the latest CPI scores Nigeria 28/100 but with a rank of 148 out of 180 countries surveyed- a significant 12 places below where it was the previous year. This is more or less a blow to the President Muhammadu Buhari administration who came into office on the strength of his anti-corruption credential. Although the administration has put some suspects on trial and seized assets of politicians and government officials, it has also been accused of condoning corrupt practices by top government officials. The index, which ranks 180 countries and territories by their perceived levels of public sector corruption in the opinion of experts and business people, uses a scale of 0 to 100 , where 0 is highly corrupt and 100 is very clean, according to Transparency International. It further revealed that Kenya, which was rated more corrupt than Nigeria in 2016, has now overtaken the West African country, climbing to 143 from 145. Other Sub-Saharan African countries ranked higher than Nigeria are Botswana- whose joint 34 rank is the best in Africa as well as Rwanda (joint 48) and Namibia (joint 53). Nigeria is ranked 148 along with Guinea and Comoros. In 2015, Nigeria scored 26/100 and was ranked 136, although only 168 countries and territories were surveyed then.

Uwak and Udofia (2016), in examining the magnitude of corruption perpetrated in government since 1999 till date, assert that corruption seems institutionalized in Nigeria. For example, some government institutions bribe legislators in order to pass the budget of their organization; some ministries demand for bribe before awarding contracts; some politicians bribe or induce electorates with money to vote them into power; some contractors connive with civil/public servants to perpetrate contract inflation; some lecturers collect money from students before they can pass examination; patients sometimes bribe nurses before they are allowed to see a doctor. Thus, the negative consequences of corruption are as countless as its various manifestations, and this has greatly affected the political, social and economic development of Nigeria.

Beyond corruption (and closely related to it) is a serious problem- wastefulness. All that is going on with Nigeria is as a result of a shocking, unmindful and heartless culture of waste. Nigerians seem to care less about the value of our resources. A single person gets into political or bureaucratic positions and empties the treasury. For the average top civil servant or politician, no amount of money is too big to grab and waste. Again, Nigeria is a place where harebrained projects are embarked upon with public money and abandoned for fun. More than 10,000 of such projects dot the country. A report, according to Ayodele and Alabi (2011), stated that there are thousands of abandoned public sector projects which would require over $\$ 600$ billion and about three decades to complete. They further averred that the issue of abandoned projects has not been given any serious attention by successive governments in Nigeria.

Again, Nigeria is a country where there is no need to have a proper plan for spending the commonwealth, and where people who consider themselves 'lucky' grab as much as they can from people's taxes, rates, duties and fines, including proceeds of wasting natural resources, just because they are close to such monies, and have the power to. Every yearly national budget is a charade, with some government officials inserting all sorts of irrelevances for their own fancy. The 2017 national budget was widely reported to have been "padded" such that it became a national embarrassment. In every government ministry, department and agency, one finds expensive equipment packed at one corner, usually cannibalized by lower staff when no one is looking; luxury cars which were bought because it was the 'right' of such agencies, not necessarily because they needed them, parked in one corner or run down and abandoned. It is nothing to smash a government car or property, dump it at a mechanic workshop and move on as if nothing happened. Vouchers also abound for fancy trips to where Nigeria was not required to make any input. Nigeria is a country with no sense of 
urgency, and no value for money. Many of the people who administer Nigeria at different levels have never done a day's business before, and so they cannot be business-like in public administration. Countries that understand productivity- that actually produce things, understand the value of things.

Nigeria seems like the worst-governed country in the world- a country where senators also earn as ex-governors; where ex-governors write into state laws millions of dollars as pensions; where former governors exert so much pressure on the finances of state governments with pension payments and other entitlements draining billions of naira every year from developmental funds for the states; where ex-presidents- old men at their twilights, see nothing wrong in collecting luxury cars every four years (or huge cash in lieu). Over N37.367 billion was, according to Vanguard Newspaper January $25^{\text {th }}, 2017$ findings, spent on servicing 47 former governors from 21 states in pension payments and provision of houses, staff, and vehicles replaceable between three and four years. Bauchi State, according to same Vanguard Newspaper report, tops pension payouts to ex-governors. Payment of pension to former governors over a four-year cycle is very high in Bauchi, Rivers, Akwa Ibom, and Lagos States with former governors drawing N23.18 billion, N2.795 billion, N2.043 billion and N1.606 billion respectively over four years. The pension payments and other entitlements drawn by the governors are irrespective of the prescription of the Revenue Mobilization, Allocation, and Fiscal Commission (RMAFC) providing 300 percent severance for the governors as stated in the Certain Political Office Holders and Judicial Officers Remuneration Act. Under that Act, former governors are like lawmakers entitled to $300 \%$ of their basic salary of N2,223,705 amounting to N6,671,115 as severance pay. However, a few other states including Akwa Ibom, Yobe, Gombe, Lagos, Kano, Rivers, Kwara, and Sokoto, have earmarked outlandish annual cash transfers to the former governors. Some states, including Cross River, Kwara, Lagos, Rivers, Bayelsa, Delta, Ebonyi, Kano, Zamfara and Sokoto States have also recommended the payment of the basic salaries of the incumbent governors as yearly pension payments to their former governors.

Nigeria is a country where the poor are being rammed down deeper into poverty, where those in power revel in byzantine opulence, yet claim to be unable to pay the paltry salaries of workers while they plunder old people's pension. Successive rulers have denigrated Nigeria into an appalling enclave of imperious centralism and devious byzantinism. Obviously, no outsider will make Nigeria work until we evolve a system that can install the change we desire. We need to find quick and permanent solution to the epilepsy of our power supply, paralysis of our railway system, incapacitation of our police, ruination of our educational system, pollution of our environment, debasement of our polity and strangulation of our economy which can all be traced or linked to corruption.

The introduction of the Federal Ministry of Finance Whistleblowing Programme which is an important feature of the National Anti-Corruption Strategy (NACS) is, thus, a major milestone for the Nigerian government in its effort to tackle the multifaceted problem of corruption and waste at different levels of governance. Whistleblowing is not peculiar to Nigeria. Over fifty countries of the world have enacted national laws of whistleblowing in one form or the other to address the issue of corruption. Some include the United States of America (USA), the United Kingdom (UK), Canada, Australia, Ireland, Jamaica, India, Switzerland, Netherlands, South Africa, New Zealand, India, South Korea, Singapore, Ethiopia, Ghana, and Uganda. Kenya and Rwanda are in the process of enacting whistleblowing laws. It is against the foregoing background that this paper seeks to answer the following questions:

1) What are the factors that drive or aggravate the problem of corruption in Nigeria?

2) Is whistleblowing an effective mechanism for the control of corruption in Nigeria?

3) What are the challenges of whistleblowing in Nigeria?

4) Are there justifications for the sustenance of the whistleblowing policy in Nigeria?

\section{Methodology}

Given the nature of inquiry at hand, this paper employed the descriptive design. Data for the study were sourced from secondary sources which include journals, newspapers, magazines and internet materials. Concepts related to corruption, anti-corruption, whistleblowing, and rentierism are amply explained in order to polish their meanings for better comprehension. Hence, the study is purely exploratory and the analysis qualitatively done.

\section{Epistemic Context}

In the corruption literature, the concept of whistleblowing as a means of combating graft and waste has found diverse expressions and applications, especially within the context of rentier economy such as Nigeria. Although corruption had long been identified as the bane of Nigeria (Ogbu, 2017), it is imperative, however, to briefly explain the driver, aggravator, and sustainer of corruption in the Nigerian system.

The switch to oil economy greatly increased the political inhibitions to Nigeria's development (Lewis, 2012). Since 1958 when Nigeria began commercial oil production, the narrative of the country has followed a twisted trajectory 
dictated by powerful interests. It has created a country with one of the highest number of political leadership in Africa, of coups and counter-coups, with a bloody civil war, a corrupt, inefficient, greedy and ostentatious class of elites, and above all, an economy that is purely rentier and a politics that is overly prebendal. Oil, Irikefe (2013) avers, has made Nigeria "a parvenu puffed up by petrodollars." The growth of oil exports, according to Irikefe, created a rentier state- a government relying principally on revenues from resource rents. It is instructive to note that in the first decade after independence, the federal structure witnessed substantial fiscal decentralization such that each region with different cash crops and minerals, controlled and retained their own export revenues. Their budgetary autonomy and the reliance of regional governments on local production served as motivation for promoting and sustaining output across the economy. These motivators shifted abruptly with the commencement of petroleum exports. First, revenues and resource control were extensively concentrated in the hands of the federal government, and the fiscal discretion of the federal government was significantly increased. The replacement of regions by states (from 1967) limited the fiscal autonomy of subnational government, and the subsequent growth of petroleum exports quickly overshadowed other revenue sources (Lewis, 2012). The sharp drop in non-oil exports right from the first military incursion into politics (in 1966) prompted the concentration of control of resources at the center, thereby spurring the entry of Nigeria into the league of rentier states. Thus, the advent of military dictatorship (between 1966-1979 and 1983-1999), with its accompanying centralized command and structure, to a great extent, altered the structure of Nigerian federalism.

Arguably, the coming into effect of the 1999 constitution further transformed the once economically robust regions into beggarly states, who in today's Nigeria, exist more or less like ministries, awaiting monthly allocation from the purse of the central government for their upkeep. In looking at the shortcomings of the 1999 constitution and the overbearing roles and powers allotted to the federal government, Amasike (2017) opines that the states of Nigeria, even though they may have the ability to add value, lack the legal capacity to effectively contribute to the growth of the economy. The 1999 constitution, asides being anti-economic development, is also anti-social in the sense that the over-concentration of power at the center has engendered acrimonious ethnoreligious and geopolitical rivalry amongst Nigeria's ethnic groups and states who appear suffused in a perpetual contest for domination and the corruptly termed "national cake". Section 44(3) and Part 1, item 39 of the $2^{\text {nd }}$ schedule of the 1999 constitution (that is, exclusive legislative list) clearly prevents federating units or states from harnessing non-oil mineral resources in their domains, prompting the current over-dependence by virtually every state in Nigeria on oil and the resultant revenue from it.

A rentier state is characterized by a high dependence on external rents produced by a few economic actors. Rents are typically generated from the exploitation of natural resources, not from production (labor), investment (interest), or management of risk (profit) (Jensen \& Wantchekon, 2009). The rentier state draws revenues primarily from a foreign-dominated enclave; state resources are therefore divorced from domestic output. This shifts the basic concern of governing elites from revenue generation (through taxation and expansion of the economic base) to the distribution of proceeds derived mainly from abroad. An independent revenue base reduces the pressures on ruling groups to maintain general conditions for production and allows them to use their fiscal discretion to bolster political power. A key to this strategy, according to Jensen and Wantchekon, is expansion of the public sector, which allows leaders to use employment, subsidies, public works, and development spending in the course of building an obnoxious system of patronage. For politicians, the stakes of winning and losing political office by any means are significantly heightened. For the public, the state becomes a fountain of resources and the gatekeeper of economic opportunities. For business elites, in particular, opportunities are multiplied through the government's role in allocating petroleum rents and the copious growth of the state sector. Business gravitates towards government contracts, licenses, quotas, and employment and auxiliary relationships with state enterprise. The rentier state fosters a rentier economy in which the principal avenues of accumulation are found in access to politically mediated rents and state elites are the central arbiters of resource distribution and market entry.

As a corollary, fiscal discretion, a lack of transparency and accountability, and abundant pressures for special preferences generate massive corruption and a culture of waste throughout the public and private sectors. The resultant effect of the aforementioned scenario is institutional decline or failure, indiscipline and inconsistency among government officials due to the fact that state officials often times connive with civilians to perpetuate corruption and corrupt acts in society by promoting their personal interest which takes precedence over state interest as typically seen in Nigeria.

Economists in the early twentieth century used the term "rentier state" to refer to the European states that extended loans to non-European governments. Mahdavy (1970) is widely credited with giving the term its current meaning: a state that receives substantial rents from "foreign individuals, concerns or governments." Beblawi (1987) later refined this definition, suggesting that a rentier state is one where the rents are paid by foreign actors, where they accrue directly to the state, and where "only a few are engaged in the generation of this rent (or wealth), the majority being only involved in the distribution or utilization of it. 
Like most post-colonial countries, Nigeria had weak institutional foundations at independence. The petroleum boom (of 1973-1983) brought about rapid institutional expansion. The challenges of institutional design and local staffing were amplified by the precipitous growth of the civil service and a proliferation of public enterprises in the 1970s and 1980s. The budding state became strained, and government institutions suddenly sank into inefficiency, profligacy, and corruption which have continued till today.

Whistleblowing is, thus, seen in this context as one of the remedial measures for tackling the cancerous problem of the Nigerian system- corruption and waste. Transparency International (TI) (2010) sees whistleblowing as the disclosing of information about perceived wrongdoing, or the risk thereof, to individuals or entities believed to be able to effect action. Whistleblowing is increasingly recognized as an important tool in the prevention and detection of corruption and other malpractices (TI, 2010). It is an early warning system that enables an organization or government to find out when something is going wrong in time to take necessary corrective action. A whistleblower is any person, including employee, management, directors, depositors, service providers, creditors and other stakeholders of an organization or institution who reports any form of unethical behaviour or dishonesty to the appropriate authority. According to the United Nations Convention Against Corruption (UNCAC) (2003), a whistleblower is "any person who reports in good faith and on reasonable grounds to the competent authorities any fact concerning offenses established in accordance with this Convention." Within the context of this work, a whistleblower is a person who voluntarily discloses to the Federal Government of Nigeria, through the Federal Ministry of Finance or the anti-corruption agencies such as the ICPC and EFCC, a possible misconduct or violation that has occurred, is ongoing, or is about to occur with specific concerns which are in the public interest.

\section{Theoretical Explanation of Whistleblowing}

This paper reckons that to articulate a clear understanding of whistleblowing, it is imperative to briefly throw some light on the concept of "depraved Nigerian economy" as used in the paper. We begin by echoing the unflattering words of Barack Obama before and during his tenure as the President of the United States of America about Nigeria and its leadership. He said:

I hear Nigeria makes the metaphorical claim as the giant of Africa. That claim, I make bold to say, is not only unfounded but absurd. Forgive my observation. That country's claim of gianthood is only proven by the relative size of its population. Forty-eight years after bidding farewell to colonial rule, that nation is still struggling to get on its feet, like a toddler. Nigeria has clearly failed to be the beacon of hope for other African nations. Will the Nigerian people ever speak of their country as that where leaders make unselfish calculations that prepare them for the challenges of the global economy? Will they ever speak of a nation where every child, male and female, has the right to achieve his or her dream? So long as people are trapped in poverty, so long as there are evidence of gross marginalization of certain regions, so long as opportunities are open, but not for all, the dream of a true nation will remain out of reach (Obama, 2008).

If corruption attracts the death penalty for instance in Nigeria, perhaps very few people will be standing. How many businessmen and women become billionaires in Nigeria without passing through the baptistery of corruption? How many of them evade tax payment, skip levies and requisite duties on imports, and offer and take bribes? How many civil servants become billionaires without a track record of where the wind of wealth blew from? At least, 30 agencies of government were discovered not to have remitted N3.8 trillion of their operating surpluses in the five years to 2009 (Ojo, 2017). The searchlight was beamed on Joint Admissions and Matriculation Board (JAMB), Nigerian Maritime Administration and Safety Agency (NIMASA), and Nigeria National Petroleum Corporation (NNPC) at the beginning of President Muhammadu Buhari's administration. The new leadership in JAMB headed by Prof. Ishaq Oloyede, for instance, within nine months in office, paid N5 billion into federal coffers. This implies that most heads of government ministries, departments and agencies simply squander or share monies they generate without remitting same to government coffers.

In the light of the foregoing, the Theory of Two Publics is appropriate to the analysis of whistleblowing in Nigeria. This theory, as canvassed by Ekeh (1975), identifies two publics in Nigeria which are the primordial public and the civic public. The primordial public is associated with blood and kinship ties, tribe/ethnic group, region, and religion, while the civic public relates to the affinities based on socio-economic grouping such as class, status, role and professional group either in the public sector or in the private sector where individuals work. Therefore, in Nigeria, the individual in the civic public views his role and duties as moral obligations to benefit and sustain a primordial public of which he is a member. Most Nigerians tend to show more loyalty to kinship ties than civic ties. In situations of conflict of interest between the primordial public and the civic public, Nigerians tend to protect primordial interest at the expense of the civic or national interest (Azelama, 2002). That is why it is commonplace to see many Nigerians engage in unscrupulous acts within the civic public in order to satisfy or appease their primordial public. For example, many 
Nigerian public servants corruptly enrich themselves while in office and employ a greater part of the loot for the gain and satisfaction of their primordial public or kinsmen.

The implication of this phenomenon, according to Ijewereme (2013), is that as the same actor functions in the two realms- the primordial and the civic, he utilizes state apparatus to better the lot of the primordial public, resulting in pervasive corruption in the civic public (Osaghae, 1995). He sees nothing wrong with robbing the civic public in order to support the primordial public which he has close ties with. Applied to whistleblowing, the Theory of Two Publics suggests that the problems of disorderliness, graft, lawlessness, and criminality generally are to be understood as the reflections or products of the way the society organizes its economy, especially the dominant interests or ties that drive it. Anti-corruption, which enforcement constitutes the rationale for the establishment and sustenance of institutions like the Economic and Financial Crimes Commission (EFCC), Independent Corrupt Practices and Related Offences Commission (ICPC), Code of Conduct Bureau (CBB), and initiatives like the Federal Ministry of Finance Whistleblowing Programme and the Whistleblower Protection Law, is meant to prohibit the behaviours and activities deemed detrimental to the national economic and political interests of Nigeria. No doubt, societies are constituted into classes and groups with a varying degree of power or influence over political and economic decision-making. Classes and groups with dominant economic power control political decision-making, including the enactment of criminal law by the legislature, its enforcement, and interpretation by the police and judiciary respectively. Hence, whistleblowers are essential to the preservation of justice and morality in society. Similarly, in a democratic, just and equitable society largely driven by civic ties, whistleblowers have greater chances of serving as vanguard for social democracy, human rights, and socio-economic justice. Whistleblowing can be located within the social, political and economic order that law enforcement institutions are required to secure, preserve and fortify. Where the prying eyes of law enforcement agents cannot reach, whistleblowers complement such role, thereby guaranteeing the dominance of civic ties (like the passion for nation building) over primordial ties (such as blood, kinship, tribe, region, religion). Thus, whistleblowers exist to detect (activities of) those considered to be dangerous for the preservation of justice and equity in society.

\section{The Challenges of Whistleblowing in Nigeria}

The Federal Ministry of Finance Whistleblowing Policy initiative has, no doubt, gained traction.
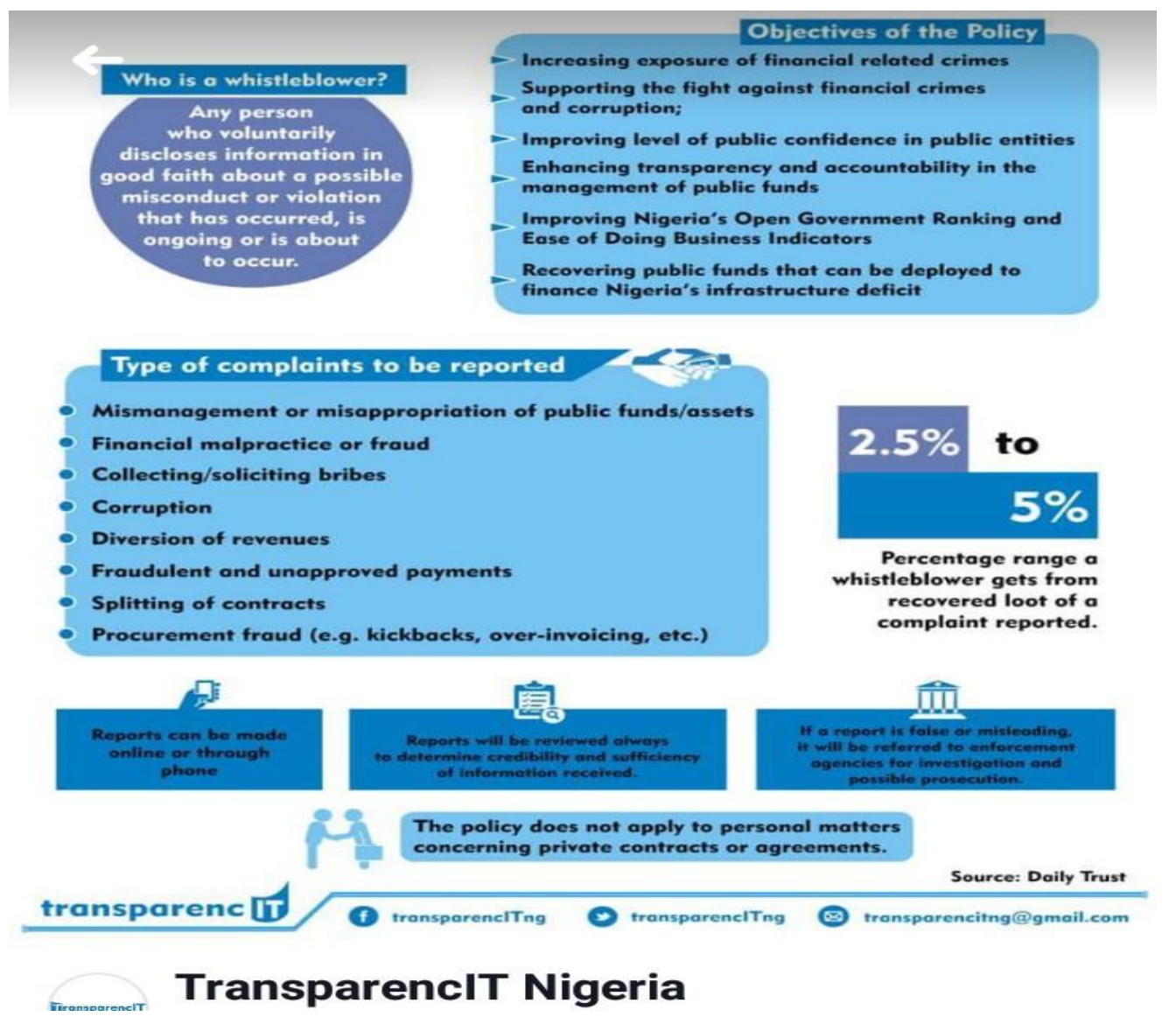

Figure 1. Nigeria's Whistleblowing Policy

Source: TransparencyIT Nigeria, 2017. 
Among the salient points of the policy as seen in the infographic above are:

(1) the possibility of increased accountability and transparency in the management of public funds;

(2) the possibility that more funds would be recovered that could be deployed in financing Nigeria's infrastructural deficit; and

(3) the possibility of improving Nigeria's open government ranking and ease of doing business indicators.

The ultimate goal is to develop a less corrupt society and attract more and more foreign investors (Akinnaso, 2016). Bahal cited in Odah (2017), however, lists insufficient legal knowledge, fear of reprisals, prebendalism/loyalty provisions, poor media reportage, lack of meaningful or robust legislation, and cultural and historical barriers, as some of the challenges of whistleblowing in Nigeria.

1. Insufficient legal knowledge:- whistleblowing is one of the ways by which the Nigerian citizen can contribute his or her own quota to the fight against graft. But unless the average Nigerian understands the provisions of the law regarding corruption and also how the law says it can be reported or fought, then the quest to end corruption might remain a tall dream. Some Nigerians only fairly understand the 1999 constitution, while some do not know what the code of conduct for public servants stipulates. Little wonder why some people readily blame the government for everything even when the government has played its own part by providing the necessary legislation or laws for society to run efficiently. Thus, while most Nigerians who are ready to blow the whistle would do so because of the financial reward of between 2.5 to 5 percent of the total money recovered, not every (would-be) whistleblower understands that according to the policy, to be entitled to the reward the whistleblower must have provided information that the government did not already have and could not obtain from any other publicly available source.

2. Fear of victimization:- this is yet another big challenge to Nigeria's Whistleblowing Policy. Political office-holders in Nigeria have an aura of invincibility around them. Therefore, a non-suicidal whistleblower would think twice before providing information on the whistleblowing portal that could incriminate the government official. One of the great fears potential whistleblowers would have is reprisal attack. As long as the offenders remain free, whistleblowers would remain in fear of being victimized. An effective whistleblowing policy cannot, therefore, operate without a true and proper reform of our political and criminal justice systems to ensure that, indeed, no one is above the law. A poignant example is the suspended member of the House of Representatives, Hon. Abdulmumin Jibrin, who brought allegations of so-called budget-padding by National Assembly members to the knowledge of the President and anti-corruption agencies. There has been no report on the outcome of the investigations into his allegations. However, for his whistleblowing, Jibrin was suspended by his colleagues for 180 days (from September 2016 to March 2017). His suspension subsisted while the legislators fingered in the budget-padding scandal in 2016 reviewed 2017 budget and as at the time of writing this paper, were reviewing 2018 budget. It is still unclear why the government has not moved against the alleged budget-padders. However, by the singular act of suspending a member for whistleblowing, the National Assembly has clearly proven the institutional suicide it is avoiding by way of foot-dragging on passing a substantive whistleblowing law and whistleblower protection law in Nigeria.

3. Prebendalism/loyalty provisions:- the longevity and success of Nigeria's whistleblowing policy still face a big challenge, namely the proper prosecution of offenders. Nigeria has not recorded a great deal of success in prosecuting looters. On the contrary, Nigerians have a penchant for recycling looters and corrupt politicians in leadership positions and idolizing their political prowess especially when they appeal to their ethnic or religious sentiments. While some are, indeed, charged to court, the suits linger as fresh news in the media overshadow the protracted trials. In no time, the accused become active politicians again and all the public sees are their opulent lifestyles. As politicians with leverage, they either begin to spin their trials as political or ethnic witch-hunts or engage in maneuverings to have the charges withdrawn or frustrate the trials; and the obnoxious system of patronage continues. Hence, it is safe to say here that for the anti-corruption war in Nigeria to effectively work, our legal and judicial system must be sanitized and strengthened because a truly independent and vibrant judiciary is very key to any anti-corruption initiative.

4. Poor media reportage:- the roles of the media, including the social media, in promoting good governance and anti-corruption are being recognized by governments and policy makers in various countries. In Nigeria, for instance, the fight against corruption that was intensified in Obasanjo's regime (1999-2007) could perhaps be seen as a straight result of the media intense reportage, coverage and exposure of corruption within the Nigerian polity during that period (Dunu, 2013). This led to the establishment of such institutions as Independent Corrupt Practices and Related Offences Commission (ICPC) and Economic and Financial Crime Commission (EFCC). However, the media in today's Nigeria seem polarized along the North-South divide that 
pervades Nigerian politics. Other factors responsible for poor quality reportage by the media are: ownership influence which affects media stand on issues; reporting of news items in a way that reflects the ideological and political considerations of the proprietor; protocol journalism which is sometimes employed to shield highly placed individuals from embarrassing questions; commercialization of news and the practice of blackmail journalism. Thus, the effectiveness of whistleblowing in Nigeria is not immune to the problem of poor media reportage as highlighted above.

5. Lack of meaningful and robust legislation:- most Nigerians, rather than blowing the whistle and expecting protection or compensation prefer to wait until the government has completed the process of enacting a formal whistleblower policy that is backed by law. So far, what we have as whistleblowing policy has remained an executive order which formulation, implementation, and monitoring are anchored by the executive branch of government. In other words, Nigerians must necessarily wait for the National Assembly, ever so conscious of its own self-protection, to enact a bill to that effect. Unless the policy is backed by law, it is more or less useless. This explains why observers have expressed concerns about the fate of the policy. Will the National Assembly quickly and willingly enact the appropriate bill, given the Senate's recent fight against the Economic and Financial Crimes Commission (EFCC), by failing to confirm the nomination of its Acting Chairman, Ibrahim Magu, and the ongoing fight against whistleblowing by the House of Representatives, which suspended the former House Appropriations Committee Chairman, Abdulmumin Jibrin, for blowing the whistle on budget padding (Akinnaso, 2016).

6. Cultural/historical barriers:- there is a strong tradition within African mores against "ratting" or telling on others. In Nigeria, the most plausible and most commonly stated reason for not blowing the whistle is given in terms of "minding one's business". Also, most Nigerians have the feelings that whistleblowing would not bring the desired societal change. Therefore, the fear of being ostracized, the perceived stress associated with being a witness to corrupt acts, perceived inefficiency of the court process, the perceived clumsiness in the whistleblowing process, the feelings that corrupt persons are too powerful, and the feelings that corruption has no direct victims, make them prefer exhibiting laissez-faire attitude towards whistleblowing. This kind of orientation often results to a cycle of primitive accumulation on a large scale.

Furthermore, in reviewing the bit of information which has been put out on the subject matter as can be gleaned from the official website of Nigeria's Whistleblower (http://whistle.finance.gov.ng/Pages/default.aspx), Odunlami (2017) asserts that the Federal Ministry of Finance has not considered:

a.) The difference between public sector and private sector whistleblowing:- the protection of whistleblowers in banks and other private/quasi-private institutions should be differentiated from the Federal Ministry of Finance Whistleblowing Programme. This is because while the former may deal primarily with curbing loss of employment and workplace victimization, the latter must, in addition, deal with protection of life, property, and freedom from government intimidation.

b.) The need to guarantee the privacy of data:- although the fundamental right of private and family life is guaranteed by the constitution of the Federal Republic of Nigeria, the policy or legislation which would regulate the Whistleblowing Programme must also guarantee that the Ministry will put in best practices to protect the data of every whistleblower.

\section{Prospects of Whistleblowing in Nigeria}

There remains an important distinction between wrongdoing in organizations that can be resolved internally which considers private and organizational interests and wrongdoing that threatens wider public interests (Arszulowicz \& Gasparski, 2011). In seeking to emphasize the public interest relevance of whistleblowing, De Maria (2005) points out that whistleblowers should be recognized as "always motivated by notions of public interest." Internationally, whistleblowing is acknowledged as a very good tool that can be used to maintain checks and balances within organizations and expose illegal practices that are being perpetuated (Agbakoba-Onyejianya, 2013). In countries like the United States of America (USA), South Korea, Japan, Sweden and Singapore, whistleblowers are protected from victimization or dismissal; they are even rewarded and celebrated. In the United States of America (USA) in 2002, three whistleblowers were awarded Time Magazine's "Persons of the Year Award", namely: Cynthia Cooper (Worldcom), Sherron Watkins (Enron Corporation) and Coleen Rowley (Federal Bureau of Investigation).

In Nigeria, no fewer than 2000 cases of whistleblowing have been recorded by the federal government in the last one year and six months, according to the Presidential Advisory Committee Against Corruption (PACAC). In the words of Bolaji Owasanoye, the Executive Secretary of the Committee,

we looked at what has worked, where it has not worked well, where we can improve and it became clear that the policy has been resoundingly successful. 
Some instances where whistleblowing has proven successful or led to huge recoveries are:

1. Cadbury Nigeria Plc: N15 billion;

2. Mike Okiro (Chairman of Police Service Commission): N275 million;

3. Dasukigate: Director of Finance (Office of National Security Adviser): US $\$ 2.2$ billion;

4. Ayo Oke/National Intelligence Agency (NIA) Saga: US $\$ 43$ million, $£ 27,000$ and N23.2 million, totaling N13.3 billion;

5. Legico Shopping Plaza (BDC Shop, Victoria Island): N448.5 million;

6. Kaduna Airport Drama: N49 million; and

7. Andrew Yakubu Saga: \$9.8 million and other Currencies.

However, as at the time of writing this article, there is no provision, either in an Act of National Assembly of Nigeria or a Law of any state in Nigeria expressly protecting whistleblowers, either in the public or private sectors. Nevertheless, there are three bills, namely: The Witness Protection Bill; The Whistleblowers' Bill; and The Public Interest Disclosure Bill at various stages of legislative process before the National Assembly. The government, thus, has a window of opportunity to standardize the whistleblowing policy by amalgamating these bills into comprehensive legislation. This, if done, could greatly curtail the risk of retaliation and backlash against potential whistleblowers.

A comprehensive and well implemented legal framework for whistleblowing is very necessary for a society like Nigeria with complex political and socio-economic relations coupled with its notorious history of corruption. The lack thereof, according to Akinkugbe (2017), can create more risks for the whistleblower. Although the Senate at its plenary session on 8th June, 2017 passed the Witness Protection Programme (Establishment, etc.) Bill, the Bill is technically not yet law.

Whistleblowing policy is indeed a laudable initiative not only in fishing out corrupt citizens, but also to serve as a deterrent to the continuity of the menace called corruption. However, it must be clearly understood that whistleblowing is a risky activity which may involve, among others, death or threat to both the whistleblower and his family. Therefore, it will be wise on the part of the Federal Ministry of Finance to put extra effort into ensuring that the trust reposed in it is firmly kept and for the National Assembly to expedite action on the formalization of the policy.

It is important to stress also that corruption in Nigeria does not exist at the federal level alone. In the fight against corruption, attention is often keenly put on "Abuja". Efforts are not made to deploy the top-down approach. Majority of the states in Nigeria do not subscribe or key into the federal government policy of fighting corruption. As a result, some of the rots, embezzlements, and avenues of waste at the state level cannot be exposed. Section 15, subsection 5 of the 1999 constitution clearly states that the Nigerian state shall abolish corrupt practices and abuse of office. The Nigerian state includes the federal government, state government, and local government. In reality, apart from the federal government and Kano State which has an anti-corruption commission, no other state in Nigeria is fighting corruption. Faboade (2018) reckons that people participate more when a programme is brought nearer to them. Hence, the apparent indifference or nonchalance of states can make the policy less popular. The longevity of the policy can be greatly affected if its implementation is limited to the federal level of government.

\section{Conclusion and Policy Implications}

Many at times, corruption exists in situations where there is little or no accountability and transparency environment at public offices. Whistleblowing is essential because it promotes accountability and good governance. Transparency International (2010), regarding the role of whistleblowing in fighting corruption, states:

......by helping to detect corruption cases, whistleblowers play a critical role in converting a vicious cycle of secrecy into a virtuous cycle. Detection of corruption is a pre-condition to initiate related investigations and prosecution. However, only if corruption cases are effectively prosecuted can a culture of corruption change (TI, 2010: 2).

Corruption in Nigeria is bleeding the economy dry. Corruption cases are lost for a number of reasons such as lack of political will, inadequate funding of the anti-graft agency to enable it to carry out thorough investigations before prosecution and publication of information; the quality of lawyers working on the cases; and the fact that many Nigerians still find it difficult to disclose information for fear of reprisals by the authorities involved. The whistleblower serves a vital function in government and business. When government agencies step over legal and ethical lines, whistleblowers can make these practices public knowledge, which can lead to violators being held accountable.

The paper observes that the interest of citizens for more information about the whistleblowing policy indicates public willingness to report financial crimes and corruption. The implications for government policy which emerge from the foregoing discussion can be summarized as follows: 
1. The Federal Government should broaden its anti-corruption fight by extending it to states, local government authorities, the military, educational and health institutions, and the private sector. The wider the scope of the fight, the more citizens will get involved.

2. The whistleblowing policy should be should be delicately formulated, assertively promoted to the public, and speedily sent to the National Assembly for consideration and passage.

3. In view of the workload of the Federal Ministry of Finance, this paper suggests that the housing and anchoring of the Whistleblowing Programme in the ministry should be critically reviewed considering the fact that there will be better synergy between the whistleblowing programme or policy and the Economic and Financial Crimes Commission (EFCC) which prosecutes reported economic and financial crimes.

4. Lastly, the Whistleblowing policy will fare well as a component of an all-inclusive anti-corruption policy. Hence, there's a need to review the country's anti-corruption policy with the hope of making it more comprehensive and effective.

\section{References}

Agbakoba-Onyejianya, B. (2013). The Whistleblower as a Gatekeeper of Good Governance. (Online Article) Retrieved from

https://www.businessdayonline.com/companies/professional-services/article/the-whistleblower-as-a-gatekeeper-ofgood-governance/ on June 21, 2018.

Akinkugbe, O. D. (2017). Recalibrating Nigeria's Whistleblowing Policy: An Urgent Plea for a Comprehensive Whistleblower Protection Legislation. (Online Article) Retrieved from http://www.google.com/amp/s/africlaw.com/2017/10/18/recalibrating-nigerias-whistleblowing-policy-an-urgent-pl ea-for-a-comprehensive-whistleblower-protection-legislation/amp on August 4, 2018.

Akinnaso, N. (2016). Nigeria's Whistleblower Policy. (Online Article) Retrieved from http://www.punchng.com/nigerias-whistle-blower-policy/ on May 8, 2018.

Amasike, U. (2017). Nigeria's Non-Oil Export Sector and the Quest for Federalism. (Online Article) Retrieved from https://opinion.premiumtimesng.com/2017/07/23/nigerias-non-oil-export-sector-and-the-quest-for-federalism-by-u gochukwu-amasike/ on July 20, 2018.

Arszulowicz, M., \& Gasparski, W. W. (2011). Whistleblowing: In Defense of Proper Action. New Brunswick, NJ: Transaction Publishers.

Ayodele, E. O., \& Alabi, O. M. (2011). Abandonment of Construction Projects in Nigeria: Causes and Effects. Journal of Emerging Trends in Economics and Management Sciences (JETEMS), 2(2), 142-145.

Azelama, J. U. (2002). Public Enterprises Management in Nigeria. Benin-City, Nigeria: Ambik Press.

Beblawi, H. (1987). The Rentier State in the Arab World, in Beblawi, H. and Giacomo L. (ed.), The Rentier State. New York: Croom Helm.

De-Maria, W. (2005). Whistleblower Protection: Is Africa ready? Public Administration Development, 25(3), 217-226. https://doi.org/10.1002/pad.343

Dunu, I. (2013). Good Governance in Nigeria: What Role for the Media. European Scientific Journal, 9(32), 178-197.

Economic and Financial Crimes Commission Act (2004). News and Information Bulletin.

Ekeh, P. P. (1975). Colonialism and the Two Publics: A Theoretical Statement. Comparative Studies in Society and History, 17, 91-112. https://doi.org/10.1017/S0010417500007659

Faboade, T. (2018). Whistleblowing: Another Abandoned Policy? (Online Article) Retrieved from https//:www.tribuneonlineng.com/159608 on September 20, 2018.

Ijewereme, O. B. (2013). An Examination of Anti-Corruption Crusades in Nigeria: Issues and Challenges. The Quarterly Journal of Administration, 33(1), 108-127.

Irikefe, P. (2013). An Inconvenient Truth. (Online Article) Retrieved from www.risenetworks.org/an-inconvenient-truth on September 15, 2018.

Jensen, M., \& Wantchekon, L. (2009). Resource Wealth and Political Regimes in Africa. Comparative Political Studies, 37, 618-841.

Lewis, P. M. (2012). The Dysfunctional State of Nigeria. Short of the Goal: US Policy and Poorly Performing States, Washington DC: Centre for Global Development, 83-116. 
Mahdavy, H. (1970). "The Patterns and Problems of Economic Development in Rentier States: The Case of Iran," in M. A. Cook, ed., Studies in Economic History of the Middle East. London: Oxford University Press.

Obama, B. (2008). Nigeria claiming giant of Africa is absurd, idiotic and laughable. (Online Article) Retrieved from htps://www.mcebisco.com.ng./2017/10/Nigeria-claiming-giant-of-africa-is.html?m=1 on April 30, 2018.

Odah, A. (2017). Whistleblowing: Corruption and the Challenges of Public Disclosure. Paper presented at the roundtable on whistleblowing in Nigeria organized by Rosa Luxemburg Stiftung West Africa at the University of Abuja as part of its Youth and Politics Programme.

Odunlami, A. (2017). A Look at Whistleblower Protection Policies in Nigeria. (Online Article) Retrieved from https://paradigmhq.org/is-there-really-a-provision-to-protect-whistleblowers-in-nigeria/ on October 15, 2018.

Ogbu, S. K. (2017). Whistleblowing Policy as a Mechanism for energizing The 'War against Corruption' in Nigeria. International Journal of International Relations, Media and Mass Communication Studies, 3(4), 16-32.

Ogundiya, I. S. (2009). Political Corruption in Nigeria: Theoretical perspectives and some explanations. Anthropologist, 11, 281-292. https://doi.org/10.1080/09720073.2009.11891117

Ojo, F. (2017). Corruption: Nigeria's Giant Struggle. (Online Article) Retrieved from http://www.opinionnigeria.com/corruption-nigerias-giant-struggle-by-fola-ojo/\#sthash.xvJRrBKh.dpbs on April 21, 2018.

Osaghae, E. E. (1995). Structural Adjustment and Ethnicity in Nigeria (Research Report No. 98). Uppsala, Sweden: Motala Grafiska, Motala.

Otite, O. (1986). The Sociological Study of Corruption, in F. Odekunle (Ed.) Nigeria: Corruption in Development: Proceedings of the Nigerian Sociological Association, Zaria.

The 1999 Constitution of the Federal Republic of Nigeria. (Online Resource) Available at www.nigeria-law.org/ConstitutionOfTheFederalRepublicOfNigeria.htm.

Transparency International (2010). Corruption Perception Index for 2010. (Online Resource) Available at https://www.transparency.org/cpi2010/results.

Transparency International (2017). Corruption Perceptions Index. Surveys released $21^{\text {st }}$ February, 2018. (Online Resource) Available at https://www.transparency.org/news/feature/corruption_perceptions_index_2017

United Nations Convention Against Corruption (UNCAC) (2003). (Online Resource) Available at https://treaties.un.org/pages/viewdetails.aspx?src=ind\&mtdsg_no=xviii-14\&chapter=18\&lang=en.

Uwak, U.E. and Udofia, A.N. (2016). Corruption in Nigeria's Public Sector Organizations and Its Implication for National Development. Mediterranean Journal of Social Sciences, 7(3), 27-35. https://doi.org/10.5901/mjss.2016.v7n3s1p27

Vanguard Newspaper (2017, January 25) How States Spent $\$ 37.367 \mathrm{bn}$ on Pensions of 47 Ex-Governors, Deputies. (Online Resource) Retrieved from https://www.vanguardngr.com/2017/01/how-states-spent-n37-367bn-0npensions-of-47-ex-govs-deputies/amp/ on October 25, 2018.

\section{Copyrights}

Copyright for this article is retained by the author(s), with first publication rights granted to the journal.

This is an open-access article distributed under the terms and conditions of the Creative Commons Attribution license which permits unrestricted use, distribution, and reproduction in any medium, provided the original work is properly cited. 